\title{
'Johnny I Want My Liver Back': Revisiting a Teenage Folktale in the Digital Age
}

\author{
Michael Wilson
}

\begin{abstract}
In the early 1990s, whilst conducting fieldwork for doctoral research into the oral narrative traditions of teenagers in Britain and Ireland, I collected many versions of a story called 'Johnny, I want My Liver Back'. The story was particularly popular amongst younger teenagers and was a 'jump' story, a tale that employs a closing formula that increases the tension of the narration and ends with the storyteller shouting the final words in order to give the listener a start. The story tells of a young boy (Johnny) who is sent on an errand to buy some liver for tea. On the way he gets distracted and spends the money on sweets, so instead goes to the graveyard and steals the liver from a freshly buried corpse. That evening the ghost of the deceased returns to reclaim the stolen organ. It is a story that is primarily a variant of 'The Man from the Gallows' (ATU 366), but also draws heavily from some versions of 'Little Red Riding Hood' (ATU 333), formerly 'The Glutton' (AT 333), notably the story of 'Uncle Wolf,' as published by Calvino in Italian Folktales (1980). This chapter provides an analysis of the story, but also explores how the story has fared in the hands of a new generation. Since then we have witnessed the arrival of the internet, Web 2.0 and self-publication via platforms such as YouTube. This chapter explores the story in the online space and its modern presentations in the global storytelling space. Through examples it shows that oral narrative traditions appear to be alive and well amongst today's teenagers.
\end{abstract}

Key Words: Teenage oral storytelling, Online storytelling, Folktales, Oral traditions, Ghost stories.

$* * * * *$

In 1990 I was making my living as a professional storyteller, working mainly in secondary schools with children in the 11-14 age range. One reason I was particularly interested in working with this age group was that whenever I told people what I did for a living, their response was invariably, 'Oh, but teenagers aren't interested in storytelling. Teenagers don't tell stories. They have no stories to tell.' And yet, as I travelled around, I knew from experience that the opposite was true: whenever I told stories to young teenagers, they always came up to me at the end of the session with stories of their own to tell. Teenagers were the most active of all storytellers; the problem was that most of them were reluctant to share them with adults. That in itself was not surprising since when they did tell their stories outside of their own peer group, I witnessed time and again teachers dismissing those stories out of hand as childish or simplistic or irrelevant. 
However, I also became aware that wherever I went around Britain and Ireland the same stories were being told in multiple variant forms by teenagers everywhere. Moreover many of those stories shared remarkable similarities with traditional tales, whether through motif, structure, purpose or function. Teenagers, it seemed, had their own rich and vibrant folk narrative traditions. ${ }^{1}$

So, as I went around I started to take a cassette recorder with me (it was a mono recorder about the size of a Walkman) and, without anything more than a rudimentary grasp of fieldwork methodology, began to record these teenage storytellers until, in no time at all, I had established a sizeable archive of material. Three years later this archive became the starting point of my doctoral study.

One of the most popular and widespread stories amongst teenagers at the time was one that usually carried the title, 'Johnny, I Want My Liver Back!'. This is the version I collected on 11 November 1993 from Natasha Tillbrook, a 13-year old girl from Gillingham School in Dorset:

There was this boy and he was given some money by his mother to go down to the butcher's and buy some liver.

So he went down and he saw a funeral procession on the way, and he thought, 'Well, if I just buy some magazines, I can collect the liver on the way back from the body.' So he goes down and buys lots of magazines with the money.

He comes back and he goes into the graveyard and luckily everyone had gone into church cos it had started raining and they hadn't covered it over - the coffin was just there. So he opened the coffin and cut the liver out and put it in a plastic bag and took it home to his mum.

Anyway, his mum made it into a liver and bacon casserole and the family had it for tea that evening, but he said he wasn't feeling very hungry, so he had a boiled egg.

Later that evening he was in bed and he heard:

'Johnny, I want my liver, I'm in the graveyard.'

And he thought, 'Oh, I must be dreaming.' And a bit later he heard:

'Johnny, I want my liver, I'm on your doorstep.'

And he was frightened then. He hid under the covers. Then he heard:

'Johnny, I want my liver, I'm on your staircase.'

And he was really frightened and he was hiding under his sheets and he was hoping that he was just dreaming it. Then he heard:

'Johnny, I want my liver, I'm by your door now.'

He was really frightened, hiding. Then he heard:

'Johnny, I want my liver, I'm by your bed.' 
Then he heard:

'Eerrgh. Johnny, I love you, I've got my liver.'

And in the morning his parents found the boy dead with his liver cut out. $^{2}$

Another variant, with a different and more common ending, came from 13 year-old Jamie from Spark Youth Club in Okehampton, Devon, on 23 October 1992:

There was this lad and his mum and dad asked him to go down to the shops to buy some liver and the mum gave him the money and he set off down the road. He kept on down the road and he passed a sweet shop and he goes in and buys some sweets instead of a liver.

So he walks past the church, so he goes, 'I've got an idea,' or something. He goes into the churchyard and digs up his gran. Then he gets hold of a little penknife, cuts his nan's liver out and runs home.

He gives the liver to his mum, she cooks it for tea and... 'Mmm, nice dinner' and all that.

So a couple of hours later his mum and dad went out to a meal, see, and Johnny was up doing his homework and downstairs her could heard (sic):

Johnny, I want my liver back, Johnny, I'm on the first step, Johnny, I'm on the landing, Johnny, I want my liver back, Johnny, I'm in your bedroom, Johnny, I want my liver back, Johnny, I'm on the pillow-case, Johnny, I want my liver back, Johnny, I'm on your he-ad, Johnny... BOO! $!^{3}$

The 'jump' ending is redolent of the well-known story 'The Golden Arm', collected and published by the Victorian folklorist Joseph Jacobs, whereby a man marries a young woman with an arm of solid gold, which he covets so much that when she dies, he robs the grave of the golden arm and place it under his pillow. That evening the ghost of his dead wife returns to avenge the theft with the following words:

"What hast thou done with thy red rosy lips?" 


\begin{abstract}
"All withered and wasted away."
"What hast thou done with thy golden hair?"

"All withered and wasted away."

"What hast thou done with they golden arm?"

"THOU HAST IT!"
\end{abstract}

The story is included in Katherine Briggs's monumental four-volume $A$ Dictionary of British Folk-Tales alongside a number of similar stories, including one called 'The Liver', first published one hundred years ago. ${ }^{5}$ Principally it is a variant of tale type ATU366 'The Man from the Gallows' in which:

A man (woman, child) takes the liver (lung, heart, stomach, backside) of a corpse who has been hanged (other dead person). At home the meat is eaten (often without knowing what it is [G60]). At night the dead person appears, asks for the stolen part of his body, and punishes the perpetrator (eater) by carrying him away (to hell) or by killing him. ${ }^{6}$

A similar story ('Der Mann vom Galgen') was also collected by the Brothers Grimm and published as a fragment in volume 3 of the 1856 edition of Kinder und Hausmärchen. ${ }^{7}$ However, Johnny's story also seems to draw substantially from tale type ATU 333 'Little Red Riding Hood' (previously 'The Glutton'). The errand on behalf of the mother, the eating of the grandmother (or something equally unpleasant) and the pursuit of the child are all motifs that are commonly found in variants of 'Little Red Riding Hood'. The variant published by Italo Calvino in Italian Folktales, entitled 'Uncle Wolf', where it is the child, rather than the wolf, that is characterised as the glutton in a subversive role-reversal, is particularly redolent of the teenage tale. ${ }^{8}$ It ends thus:

When it was night and the child was already in bed, Uncle Wolf's voice was heard outside the house. "I'm going to eat you now, I'm right outside!" Then a footstep was heard on the roof. "I'm going to eat you now! I'm on the roof!"

Then a clatter was heard in the chimney. "I'm going to eat you now! I'm in the chimney!"

"Mamma, Mamma! The wolf is here!"

"Hide under the covers!"

"I'm going to eat you now! I'm on the hearth!"

Shaking like a leaf, the child curled up as small as possible in a corner of the bed.

"I'm going to eat you now! I'm in the room!"

The little girl held her breath. 
"I'm going to eat you now! I'm at the foot of the bed! Ahem, here I go!" And he gobbled her up.

So Uncle Wolf always eats greedy little girls. ${ }^{9}$

It is clear that 'Johnny, I Want My Liver Back' has a convincing traditional pedigree and constituted clear evidence almost twenty-five years ago of a healthy narrative tradition amongst teenagers that could be traced back to earlier narrative traditions that were two hundred years old or more. Nevertheless, much has changed in the world of storytelling since I first collected those stories and I have for a number of years been curious as to how these traditions have survived and flourished in the hands of a new generation.

We can arguably point to two specific (and not unrelated) developments in storytelling over the past two decades. The first is that storytelling has become mainstream. We have witnessed what many sociologists have described as a 'narrative turn' ${ }^{10}$ and, as Francesca Polletta declares, 'In recent years, storytelling has been promoted in surprising places'. ${ }^{11}$ Likewise Christian Salmon, the French critic and journalist says that 'since the mid 1990s storytelling has enjoyed a surprising success in the United States that has been described as a triumph, a renaissance or a "revival". It is a form of discourse that has come to dominate all sectors of society (...) It has subsequently been likened to the dawn of a new "narrative" age'.

The second major change that has occurred is, of course, the arrival of the internet and digital technologies as ubiquitous technologies. If the teenagers I collected stories from in the early 1990s had heard of the internet, they almost certainly wouldn't have had access to it. As with all preceding generations, their storytelling would have been limited to largely face-to-face co-present interactions with people they already knew (friends, family and professionals such as teachers, youth leaders, etc.). However, the arrival of digital technologies and their widespread affordable availability (especially web-based and mobile platforms and social media) has transformed the way that we, as a society, share our stories and, in so doing, curate our lives and teenagers are pioneers in this respect. Web 2.0 has transformed what was once called the Information Superhighway into a Narrative Superhighway and we are all now publishers.

The rise of digital storytelling as a form of creative practice has been exponential in recent years and we are now able to share and exchange stories across a global network with people we do not know in countries we have never visited. ${ }^{13}$ For teenagers their audiences are no longer restricted to their friends in the classroom or the youth club, or sat around a campfire or in someone's bedroom late at night during a sleepover.

A brief Google search of 'Johnny, I Want My Liver Back' (which seems a reasonable place to begin) reveals 189,000 results. ${ }^{14}$ As might be expected this includes scholarly and information sites with an interest in contemporary folklore, 
but there is also a significant number of retellings of the story, often by children and teenagers, on social media and user-generated content sites (such as YouTube and blogging sites) and even on self-publishing sites such as Wattpad. I would, however, like to briefly consider two of the stories which are typical of larger corpus in many ways and give some indication of how the story has fared in the digital age.

The first is a short film, posted on YouTube, by a trio of American children, entitled 'scary story - Jonny I want my liver back': https://www.youtube.com/watch?v=Cgb-g6Zur98

The story roughly conforms to the common structure and motifs, except that the final part of the story is stretched out over a three-day narrative period. The storytellers themselves are pre-teenage, but what is interesting is how they have embraced the medium and the availability of technology in order to tell their story. That is to say that they tell the story as if it were a film, acting out multiple roles, without the inconvenience of having to think about costume, set, or even the demands of character acting. In this way they continue to conform to some of the stylistic performance preferences of traditional storytelling, which also minimises the use of these things. In addition they have adopted cinematic conventions such as intro and outro title sequences and soundtrack overlay. The film seems to have been made on a hand-held device and there has been little attempt to shoot from multiple angles or to edit sequences together. The camerawork is shaky and it seems likely that this is simply part of the home-made, low-production-value aesthetic, rather than a deliberate stylistic attempt to produce a faux realism, such as in The Blair Witch Project. In other words, the most striking features about this short film are that they maintain the home-made immediacy and spontaneity of oral storytelling whilst also adopting some framing that acknowledges the medium.

The second piece is a facebook posting by 'OMfG Tongan Haunted Hut of Horrors' under the title 'GHOST STORY \#837:

I wanna tell a story $i$ got from camp. Okay, so their was a family that was shopping one day. Mom, girl and boy, the father had passed away a couple of years ago. So the family was about to leave town until the mother realised she didn't get the (liver) meat for dinner. She decided to give her son money to go and buy the meat while her and the sister went home. The boy saw his mates and wanted to talk as they was walking they pasted a Candy Store. None of the mates had any money but the boy did, he choose to buy candy and forgot about the meat. As they left the store the boys, mates said they had to leave. The boy got left with nothing and was affraid to go home empty handed. So as Stupid the boy was he went to the cemetary. The boy went and dugged up his fathers grave and took his liver. 
That same night the family all ate the liver not knowing it was the descets father. That night the family all went to bed. (The boys name by the way was 'Johnny') That night while johnny was asleep he woke up to a noise at the front door saying 'JOHNNY...... I WANT MY LIVER BACK' as weird as it was johnny thought it was the wind, then falling back asleep hearing something in the kitchen rattling. 'JOHNNY..... I WANT MY LIVER BACK' again thinking it being the wind he slept hearing at the bottom steps

now.

'JOHNNY..... I I WANT MY LIVER BACK' falling asleep, then at the door. 'JOHNNY.... I I WANT MY LIVER BACK' the boy then got scared and covered himself with his blanket an tried to fall asleep, hearing a movement within his room he got sleepy not knowing. 'JOHNNY......'

from the front of the bed. To being right next to the boy 'IM NEXT TO YOU' *due to the fact the little family had eaten the descet fathers liver, because of Johnnys selfishness, that the whole family died from the concequence. Having then be found later with noe liver and cut into big pieces.

Okay, dat my story gud nite! $!^{15}$

It is not easy to determine the age of 'OMfG Tongan Haunted Hut of Horrors', but the reference to 'camp' and the use of slang and other linguistic features suggest that the writer is a teenager. As a piece of narrative text, it has a number of interesting features. On the one hand it retains a strong sense of oral language, which is in itself not unusual in online communications, but whilst the use of slang, the grammar and spelling conventions, etc., might suggest a certain sloppiness in the telling, it is in fact a carefully constructed and, indeed, presented narrative. Most strikingly is that it is framed with both an opening metatextual statement ('I wanna tell a story I got from camp') and a closing formula ('Okay, dat my story gud nite!), which is not so very different from any number of traditional story endings.

In addition, the text is very carefully laid out - note in particular the use of paragraphs and the presentation of the repetition formula with upper case letters, elipses and even inverted commas. These seem to betray a more considered artistry than might otherwise be apparent. One reading of that may be that even in the medium of faced-paced, instantaneous social networking, teenagers continue to 
exchange their stories with care and consideration, adopting a range of traditional oral and literary conventions to communicate the narrative more effectively.

Perhaps the most interesting features of both YouTube and FaceBook is that it allows others to comment on the posting. In my doctoral work and the subsequent book, I made an argument that teenagers use their traditional narratives as items of social currency and, as such, they are context-dependent. Reading the comments posted in response to these stories, I could not help but notice that the stories are continuing to be used as pieces of social exchange and that the comments here (often along the lines of 'I've heard that one before' or 'It wasn't like that, you got it wrong!') are almost identical to the peer conversations that followed the telling of a story when I was collecting twenty or more years ago.

For its own health and survival, any tradition must adapt and evolve and make itself relevant to each succeeding generation and its preferred means of communication. It is encouraging (indeed comforting) to know that in the digital age, teenagers continue to cherish and develop their traditional narratives, adapting them to their own social milieu and the means of capturing and dissemination that are available to them. 'Johnny, I Want My Liver Back', the evidence would appear to suggest, remains alive and well in the digital age.

\section{Notes}

${ }^{1}$ Michael Wilson, Performance and Practice: Oral Narrative Traditions among Teenagers in Britain and Ireland (Aldershot: Ashgate, 1997).

${ }^{2}$ Wilson, Performance and Practice, 216-7.

${ }^{3}$ Wilson, Performance and Practice, 215-6.

4 Katherine Briggs, A Dictionary of British Folk-tales, Part A, Vol. 2 (Bloomington: Indiana University Press, 1970), 530-1.

${ }^{5}$ David Rorie, 'Stray Notes on the Folk-Lore of Aberdeenshire and the North-East of Scotland', Folk-Lore, Vol. XXV (1914): 342-363.

${ }^{6}$ Hans-Jörg Uther, The Types of International Folktales: A Classification and Bibliography, Vol. 1 (FFC 284-286), (Helsinki: Folklore Fellows Communications, 2011), 230.

${ }^{7}$ Jacob and Wilhelm Grimm, Kinder und Hausmärchen, Vol. 3 (Göttingen: Verlag der Dieterich'schen Buchhandlung, 1856), 276.

${ }^{8}$ Italo Calvino, Italian Folktales (London: Penguin, 1982), 152-4.

${ }^{9}$ Calvino, Italian Folktales, 153-4.

${ }^{10}$ Christian Salmon, Storytelling: Bewitching the Modern Mind (London: Verso Press, 2010), 6.

${ }^{11}$ Francesca Polletta, It Was Like A Fever: Storytelling in Protest and Politics (Chicago: University of Chicago Press. 2006), 1.

${ }^{12}$ Salmon, Storytelling, 4. 
13 See especially: John Hartley and Kelly McWilliam, Story Circle: Digital Storytelling Around the World (Oxford: Wiley-Blackwell, 2009).

${ }^{14}$ Search made on 14 March 2014.

${ }^{15}$ OMfG Tongan Haunted Hut of Horrors, 'GHOST STORY \#837', viewed 21 May 2014, https://www.facebook.com/permalink.php?id $=326844010746120 \&$ story fbid $=450$ 390241724829

\section{Bibliography}

Calvino, Italo. Italian Folktales, London: Penguin, 1982.

Briggs, Katherine. A Dictionary of British Folk-Tales. Bloomington: Indiana University Press, 1970.

Grimm, Jacob and Wilhelm. Kinder und Hausmärchen, Göttingen: Verlag der Dieterich'schen Buchhandlung, 1856.

Hartley, John and McWilliam, Kelly. Story Circle: Digital Storytelling around the World. Oxford: Wiley-Blackwell, 2009.

Jacobs, Joseph. English Fairy Tales. London: David Nutt, 1890.

Polletta, Francesca. It Was Like A Fever: Storytelling in Protest and Politics. Chicago: University of Chicago Press, 2006.

Rorie, David. 'Stray Notes on the Folk-Lore of Aberdeenshire and the North-East of Scotland', Folk-Lore, Vol. XXV (1914); 355.

Salmon, Christian. Storytelling: Bewitching the Modern Mind, London: Verso Press, 2010.

Uther, Hans-Jörg. The Types of International Folktales: A Classification and Bibliography, (FFC 284-286). Helsinki: Folklore Fellows Communications, 2011.

Wilson, Michael. Performance and Practice: Oral Narrative Traditions Among Teenagers in Britain and Ireland. Aldershot: Ashgate, 1997.

Michael Wilson is Professor of Drama at Loughborough University, UK. His research interests lie broadly in the field of popular and vernacular performance 
and his research into storytelling has recently focused on the development and emergence of new forms of storytelling in the online world. 